\title{
A new method for closure of large donor side defects after raising the pectoralis major flap
}

\author{
Kruse, A L D ; Luebbers, H T ; Grätz, K W ; Bredell, M
}

\begin{abstract}
BACKGROUND: Although free flaps are reliable for head and neck reconstructions, the pectoralis major flap (PMF) is still often used. In cases of a large PMF, the closure of the donor side can be a challenge. CASE REPORT: A technique, originally developed for the treatment and prevention of abdominal ruptures after laparotomy, is presented as an alternative for closure of large donor side defects. CONCLUSION: The use of Ventrofil(R) is an additional option for large donor side defects and especially to bridge the period of postoperative swelling. If utilized special attention must be paid to possible pressure necrosis of the underlying skin.
\end{abstract}

DOI: https://doi.org/10.1007/s10006-010-0245-6

Posted at the Zurich Open Repository and Archive, University of Zurich ZORA URL: https://doi.org/10.5167/uzh-46025

Journal Article

Published Version

Originally published at:

Kruse, A L D; Luebbers, H T; Grätz, K W; Bredell, M (2011). A new method for closure of large donor side defects after raising the pectoralis major flap. Oral and Maxillofacial Surgery, 15(4):251-252.

DOI: https://doi.org/10.1007/s10006-010-0245-6 


\title{
A new method for closure of large donor side defects after raising the pectoralis major flap
}

\author{
Astrid L. Kruse • Heinz T. Luebbers • Klaus W. Grätz • \\ Marius Bredell
}

Received: 16 July 2010 / Accepted: 18 July 2010 / Published online: 4 August 2010

(C) Springer-Verlag 2010

\begin{abstract}
Background Although free flaps are reliable for head and neck reconstructions, the pectoralis major flap (PMF) is still often used. In cases of a large PMF, the closure of the donor side can be a challenge.

Case report A technique, originally developed for the treatment and prevention of abdominal ruptures after laparotomy, is presented as an alternative for closure of large donor side defects.

Conclusion The use of Ventrofil ${ }^{\circledR}$ is an additional option for large donor side defects and especially to bridge the period of postoperative swelling. If utilized special attention must be paid to possible pressure necrosis of the underlying skin.
\end{abstract}

Keywords Pectoralis major flap $\cdot$ Wound closure $\cdot$ Head and neck cancer

\section{Background}

Pectoralis major flap (PMF), described by Ariyan [1] in 1979, is a common flap for reconstructive head-and-neck surgery for mucosal and skin defects. One of the largest published series of 437 cases was done by Vartanian et al. [2]. The main advantages of PMF are the proximity of the head-and-neck region, the possibility of combination with a free flap, and the possibility of obtaining a large amount of tissue. In cases of large flaps, the closure of the donor side

\footnotetext{
A. L. Kruse $(\bowtie) \cdot H$. T. Luebbers $\cdot$ K. W. Grätz $\cdot$ M. Bredell

Department of Craniomaxillofacial and Oral Surgery,

University Hospital Zurich,

Frauenklinikstr. 24,

8091 Zurich, Switzerland

e-mail: astridkruse@gmx.ch
}

can be a challenge due to high tension and the risk of dehiscence. Therefore, a new method is presented in order to prevent wound dehiscence.

\section{Case report}

In a 69-year-old male patient with a squamous cell carcinoma of the left part of the mandible a PMF was raised in typical matter for reconstruction due to poor vessel quality. In order to avoid excessive tension extending incisions and rotational techniques were performed if necessary. Additionally after closure of the wound layers-muscle, fascia, and subcutaneous fatwith resorbable suture material, Ventrofil ${ }^{\circledR}$ plates (B. Braun Melsungen AG, Melsungen, Germany; Fig. 1) were applied in order to relieve tension. A plastic-coated steel wire was inserted deeply into the surrounding tissue, creating a large mattress stitch, followed by placing a plastic plate around the wire with the soft side downwards, facing the skin. Then the wires were adhered gently until the skin was closed, the wires were knotted, and finally skin clamps were used for the skin (Fig. 2). The device was left for 4 to 8 days in order to cover the period of expected postoperative swelling. The skin clamps were routinely left for 10 days.

\section{Discussion}

Special attention must be paid to pressure necrosis. Peeters and Molderez recommended using dry compresses under the plates and changing them twice daily to alter high pressure points [3]. Because this form of postoperative wound manipulation is theoretically leading to a higher risk 


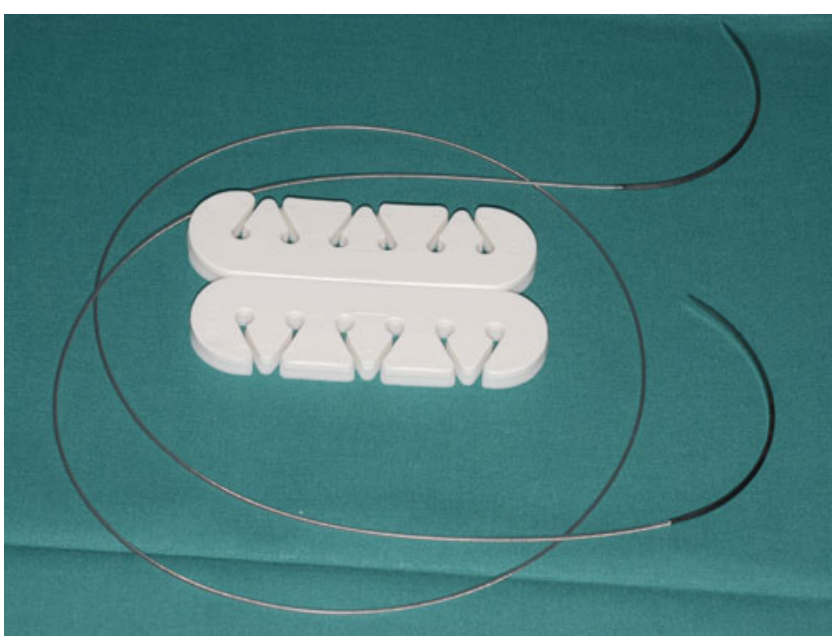

Fig. 1 Ventrofil ${ }^{\circledR}$ plates (B. Braun Melsungen AG, Melsungen, Germany)

of infection we suggest adapting the frequency depending on the observed degree of pressure onto the skin.

Ventrofil ${ }^{\circledR}$ is a special tension-relief bridging device, developed primarily for the treatment and prevention of abdominal ruptures after laparotomy [4]. It can be useful, particularly in cases of poor skin quality. An alternative can be the Suture Tension Adjustment Reel (STAR, Closure Systems, LLC Boston, MA, USA), which is based on the same principles [5]. In general, extending incisions and using rotational techniques to reduce tension to a minimum is the basic strategy in closure of donor side defects.

\section{Conclusion}

The use of Ventrofil ${ }^{\circledR}$ is an additional option for large donor side defects and especially to bridge the period of postoperative swelling. If utilized special attention must be paid to possible pressure necrosis of the underlying skin.

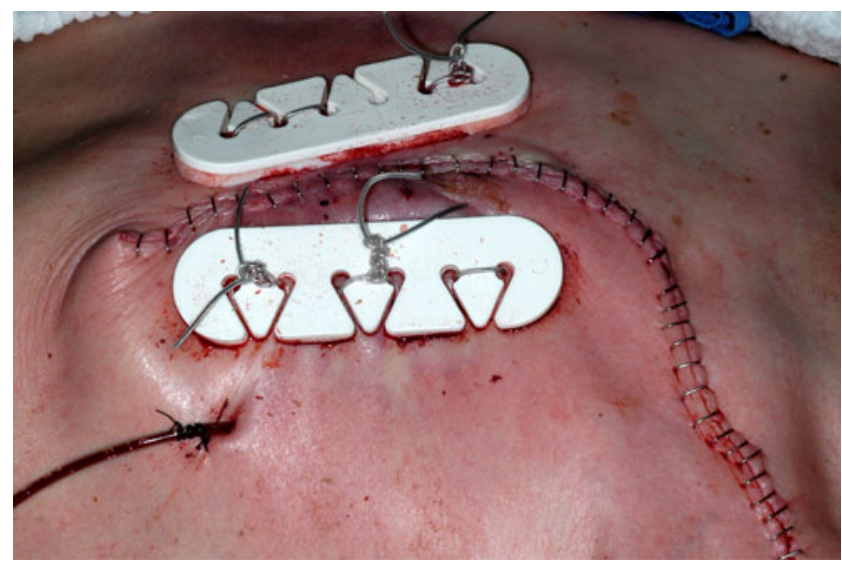

Fig. 2 Closure of the donor defect

Acknowledgment The authors would like to thank Mrs. Christa Giger for her great help with the photo documentation.

Conflict of Interest The authors declare that there is no conflict of interest.

\section{References}

1. Ariyan S (1979) The pectoralis major myocutaneous flap. A versatile flap for reconstruction in the head and neck. Plast Reconstr Surg 63(1):73-81

2. Vartanian JG et al (2004) Pectoralis major and other myofascial/ myocutaneous flaps in head and neck cancer reconstruction: experience with 437 cases at a single institution. Head Neck 26 (12):1018-1023

3. Peeters G, Molderez C (2009) Primary closure of large inelastic wounds with the use of a tension relief bridging device. J Plast Reconstr Aesthet Surg 62(12):e639-e640

4. Penninckx FM et al (1979) Abdominal wound dehiscence in gastroenterological surgery. Ann Surg 189(3):345-352

5. Atweh NA et al (2002) Closure of large abdominal wounds with an adjustable suture-tension device. J Am Coll Surg 195(2):281283 